(ํ) Entomologica Fennica. 8 July 1997

\title{
Notes on interesting scythridids in the Zoological Museum, Helsinki, Finland (Lepidoptera, Scythrididae)
}

\author{
Bengt $\AA$. Bengtsson
}

\begin{abstract}
Bengtsson, B. A. 1997: Notes on interesting scythridids in the Zoological Museum, Helsinki, Finland (Lepidoptera, Scythrididae). — Entomol. Fennica 8: 89-102.

In this paper 28 species of the family Scythrididae from Asia and Africa are treated, six of which are described as new species, viz. Scythris felesella sp. n., S. kailai sp. n., S. kullbergi sp. n., S. kyzylensis sp. n., S. subcassiterella sp. n. and $S$. terekholensis sp. n. Most of the specimens were collected during expeditions made by members of the staff of the Zoological Museum in Helsinki. Genitalia not illustrated before are described, the distribution range of each species treated is given and some other experiences are presented.
\end{abstract}

Bengt A. Bengtsson, Box 71, S-380 74 Löttorp, Sweden

Received 15 March 1996, accepted 15 April 1996

\section{Introduction}

At the Societas Europaea Lepidopterologica Meeting in Helsinki in April 1992 I was kindly invited by Jukka Jalava at the Zoological Museum to examine the scythridids kept in the museum collections. As scythridids most often are very difficult to determine only by superficial observation I was permitted to have the most interesting species, mainly from Asia and Africa, as a loan. Later on some other scythridids were sent to me for determination and in November 1995 I received 90 specimens collected in the Tuva Republic close to the Mongolian border.

Upon examination, including dissection of the genitalia, several very interesting discoveries were made, among them six undescribed species. The known distribution range was extended for many species. All these experiences are described here. Information on the distribution area is based mainly on unpublished studies made by the author, except for a few species known from Europe (see Bengtsson 1997b). The species are presented in alphabetic order as the infrageneric relationship within the family Scythrididae is still poorly understood.

\section{Examined specimens}

Catascythris kebirella Amsel, 1935

3 đ̛đ: U.A.E. (United Arab Emirates), Ras al Khaimah, shore dunes, light trap, 6.IV.1990, K. Mikkola leg.

Distribution: Israel, India, Iran, N Africa, Oman, Saudi Arabia, United Arab Emirates.

Biology: Unknown.

Remark: Not recorded from United Arab Emirates before. Genitalia are illustrated by Bengtsson (1997b).

Erigethes strobilacei Walsingham, 1907

1 Ơ': TUNISIA, Sahara semidesert, $5 \mathrm{~km}$ N Douz ad. luc., 17-18.IV.1984, K. Mikkola leg.

Distribution: Algeria, Tunisia.

Biology: Unknown. 
Remark: The adult moth and the genitalia are illustrated by Bengtsson (1997b).

\section{Scythris ammobia Falkovitch, 1972}

1 ○: Jakutsk; B. Poppius; 1364.

External appearance (Fig. 1): Forewing fuscous in different shades, markings diffuse, most prominent are small whitish and dark fuscous dashes in fold; at tip some pale scales.

Female genitalia (Fig. 2): The female genitalia illustrated by Falkovitch (1972) in his original description are very similar to those of the specimen from Jakutsk (Yakutsk). With some doubt I thus regard the Poppius specimen as ammobia.

Distribution: Uzbekistan, Russia (E Siberia).

Biology: Unknown.

Remark: This specimen was collected in the 19th century and represents the first known find from Russia.

Scythris sp. (pr. amphonycella (Geyer, (1836)))

$10^{\top}$ and 1 \%: USSR $43^{\circ} \mathrm{N} 43^{\circ} \mathrm{E}, \mathrm{C}$. Caucasus, KabardinoBalkarskij zap. $35 \mathrm{~km}$ SE mt. Elbrus, alpine meadow $2600 \mathrm{~m}$, 12.VII.1990, J. Jalava leg.

Male genitalia (Fig. 3a, b): Most significant differences from amphonycella are: (1) the shape of uncus that is deeply cleft in amphonycella and with narrower uncus lobes, and (2) valvae are not evenly tapered as in the Caucasian specimen but always widest at middle and rapidly tapered to a point terminally (cf. Bengtsson 1997b).

Female genitalia (Fig. 4): Very similar to those of cuspidella (Denis \& Schiffermüller, 1775), flavilaterella (Fuchs, 1886) and obscurella (Scopoli, 1763) (cf. Bengtsson 1997b).

\section{Biology: Unknown.}

Remark: The male and female specimens from Caucasus most likely do not belong to amphonycella or another described species of the critical obscurella species group as the specimens are smaller, and forewing is slightly darker and has different coloration from other species of the group. Yet I refrain from describing a new species until more material is available for study.

\section{Scythris baikalensis Bengtsson \& Liška, 1996}

$110^{\circ} 0^{\top}$ and 1 o: RUSSIA Tuva rep., $50^{\circ} 16^{\prime} \mathrm{N} 94^{\circ} 54^{\prime} \mathrm{E}$, $1250 \mathrm{~m}$, ca. $25 \mathrm{~km} \mathrm{~W}$ Erzin, steppe/stony slopes 711.VI.1995, Jalava \& Kullberg leg.

$80^{\circ} 0^{\top}$ and 4 OO: RUSSIA Tuva rep., $50^{\circ} 45^{\prime} \mathrm{N} 94^{\circ} 29^{\prime} \mathrm{E}$, $1250 \mathrm{~m}$, E. Tannu-Ola mts., $5 \mathrm{~km}$ ENE Khol-Oozha, steppe slopes 16-19.VI.1995, Jalava \& Kullberg leg.

$60^{\top} \mathrm{O}^{\top}$ and 5 oO: RUSSIA Tuva rep., $52^{\circ} 04^{\prime} \mathrm{N} 94^{\circ} 22^{\prime} \mathrm{E}$, 670 m, Ust-Ujuk, steppe hills 3-5.VI.1995, Jalava \& Kullberg leg.

$30^{\circ} 0^{\circ}$ and 3 of: RUSSIA Tuva rep., $50^{\circ} 45-50^{\prime} \mathrm{N}$ $92^{\circ} 29^{\prime}-94^{\circ} 19^{\prime} \mathrm{E}, 1250-2000 \mathrm{~m}$, E. Tannu-Ola mts., steppe/ meadow/forest 8.VI.1995, Jalava \& Kullberg leg.

$20^{\circ} 0^{\prime \prime}$ and 2 Q⿱宀 $1150 \mathrm{~m}$, Lake Tere-Khol, sand dunes 9-12.VI.1995, Jalava \& Kullberg leg.

$1 \mathrm{O}^{\prime}$ : RUSSIA Krasnojarskij kr., 52 $47^{\circ} \mathrm{N} 93^{\circ} 18^{\prime} \mathrm{E}$, $1230 \mathrm{~m}$, W-Sajan mts., subalpine meadow/taiga, 2022.VI.1995, Jalava \& Kullberg leg.

Female genitalia (Fig. 5): Sterigma a weak membrane, posteriorly bristled. Ostium area minutely spined posteriorly. Antrum funnelled, distinct.

Biology: Unknown.

Remarks: S. baikalensis was recently described (Bengtsson \& Liška 1996) and the male genitalia were then illustrated. The species is so far only found in the Baikal area west of the Yenisei River.

\section{Scythris bifissella (Hofmann, 1889)}

$10^{\top}$ : RUSSIA Tuva rep., $50^{\circ} 44^{\prime} \mathrm{N} 93^{\circ} 08^{`} \mathrm{~N}, 1000 \mathrm{~m}, \mathrm{E}$. Tannu-Ola mts., Irbitei r., stony steppe slopes, 1316.VI.1995, Jalava \& Kullberg leg.

Male genitalia (Fig. 23a, b): Small differences may be observed between European and Asian specimens, primarily in the shape of uncus and valva. Cf. Bengtsson (1984) and Bengtsson and Liška (1996).

Female genitalia: Illustrated by Bengtsson (1984, 1997b).

Distribution: C Europe and the Baikal area.

Biology: Occurring in steppe habitat, mostly in mountainous areas. Adults emerge in June. Reared from Silene otites (see Bengtsson 1997b).

Remark: The specimen found in Tuva (Fig. 22) has a larger wingspan (13 mm) compared with European specimens (maximum $11.5 \mathrm{~mm}$ ) and the gloss on the forewing is stronger. Nevertheless I 

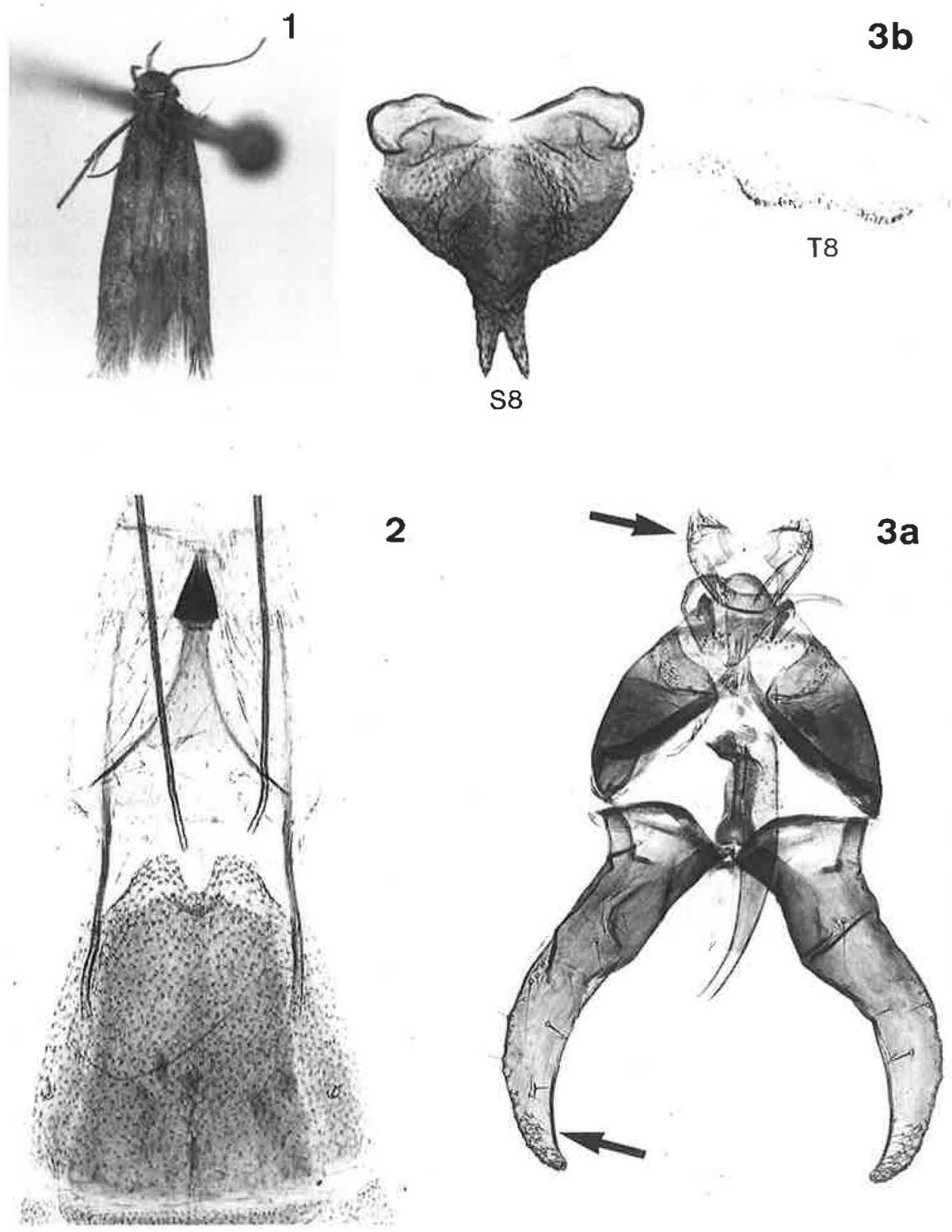

Figs. 1-3. - 1: Imago of Scythris ammobia Falk. -2: Female genitalia of $S$. ammobia. - 3: Male genitalia of Scythris sp. (pr. amphonycella (Geyer)). a: Uncus/gnathos/tegumen/valva/aedeagus. b: Sternum 8 (left) and tergum 8 (right).

consider it provisionally to belong to Scythris bifissella which is a member of the pascuella species group composed by S. pascuella (Zeller, 1855),
S. paullella (Herrich-Schäffer, 1855), S. pudorinella (Möschler, 1866) and at least a dozen more species (see Bengtsson 1997b). 
Scythris canescens (Staudinger, 1880)

1 ơ: TUNISIA, Douz Oasis, 16.IV.1984, K. Mikkola leg. 1 O’: Maroc, Ait-Melloul pr Oued Sous, 13-15.II.1961, Meinander.

Distribution: Afghanistan, Algeria, Libya, Morocco, Pakistan, Syria, Tunisia, Turkey.

Biology: Unknown.

Remark: Genitalia are illustrated by Bengtsson (1997b).

\section{Scythris capitalis (Erschoff, 1874)}

1 ơ $^{\top}$ and 3 申O: Kopet Dagh; Ahnger; 304, 305, 306 and 307 respectively.

Male genitalia: Described by Bengtsson and Liška (1996).

Female genitalia (Fig. 6): Sterigma hoodshaped, posterior margin rounded and anterior one slightly concave, there attached to a membrane with longitudinal folds. (Unfortunately some irremovable debris are included in Fig. 6.)

Distribution: Found in C and SW Asia (Kirghistan, Russia, Tadzhik Republic, Turkey, Turkmen Republic, Uzbekistan).

Biology: Unknown.

\section{Scythris cassiterella (Snellen, 1884)}

$1 \sigma^{\top}$ : RUSSIA Tuva rep., 50 $01^{\prime} \mathrm{N} 95^{\circ} 03^{\prime} \mathrm{E}, 1150 \mathrm{~m}$, Lake Tere-Khol, sand dunes, 9-12.VI.1995, Jalava \& Kullberg leg.

1 @: Mont.Verhojansk; B. Poppius; 3479.

Distribution: Found in several places from Amur and Verkhoyansk in E Siberia to Baikal area in C Asia.

Biology: Unknown.

Remark: Genitalia are illustrated by Bengtsson and Liška (1996).

Scythris fallacella (Schläger, 1847)

$10^{\Re}$ : Coll. Duske, Sarepta.

Distribution: C and S Europe to Turkey and Sarepta (Krasnoarmeysk) at Volga River.

Biology: Hostplant Helianthemum.
Remark: This record extends the known distribution area considerably to the northeast. Genitalia are illustrated by Bengtsson (1984).

Scythris felesella Bengtsson sp. $\mathrm{n}$.

Holotype: 1 ㅇ: USSR $43^{\circ} 24^{\prime} \mathrm{N} 75^{\circ} 2^{\prime} \mathrm{E}$, Kazakhstan, Dzhambulskaya obl., 70 km NNE Frunze; $950 \mathrm{~m}$, rocky slope, 18.VII.1990 ad luc. L. Kaila leg. Genitalia on slide L. Kaila prep. no. 531, - In Zoological Museum, Helsinki.

Diagnosis: The moth resembles some small and pale species from North Africa and South Asia but genitalia are different.

External appearance (Fig. 8): Wingspan $7 \mathrm{~mm}$. Head greyish beige. Antennae 0.6 of forewing length, pale brownish; scape with long bone-coloured pecten. Labial palpi slender, slightly upcurved, second joint bone coloured, third joint pale fuscous, both joints of equal length. Tegulae, thorax and forewings of same colour, pale greyish beige with faint reddish tinge, without gloss. Hindwings slightly paler than forewing. Forewing and hindwing cilia bone-coloured. Hindlegs pale beige but anterior part of tarsi brownish. Coloration of abdomen unknown.

Male genitalia: Unknown.

Female genitalia (Fig. 7): Sterigma a small, squared hood with delicate structures and with membraneous extension anteriorly. Ostium weakly marked, antrum visible, curved. Sternum 7 elliptical, anterior margin strongly reinforced by a sclerotized band.

Distribution: Only known from the type locality in Kazakhstan.

Biology: Unknown.

Etymology: The species name is referring to the profile of segment 7 resembling a cat's head (feles $=$ 'cat' in Latin).

Remark: At the moment nothing can be stated about the relationship to other species. The discovery of the male might reveal to what group felesella should be assigned.

Scythris flavilaterella (Fuchs, 1886)

$60^{\top} 0^{\top}$ and 2 OO: USSR $43^{\circ} \mathrm{N} 43^{\circ} \mathrm{E}, \mathrm{C}$. Caucasus, KabardinoBalkarskij zap. $35 \mathrm{~km}$ SE mt. Elbrus, alpine meadow $2600 \mathrm{~m}$, 12.VII.1990, J. Jalava leg. 1 ६: Coll. Duske (no other data). 

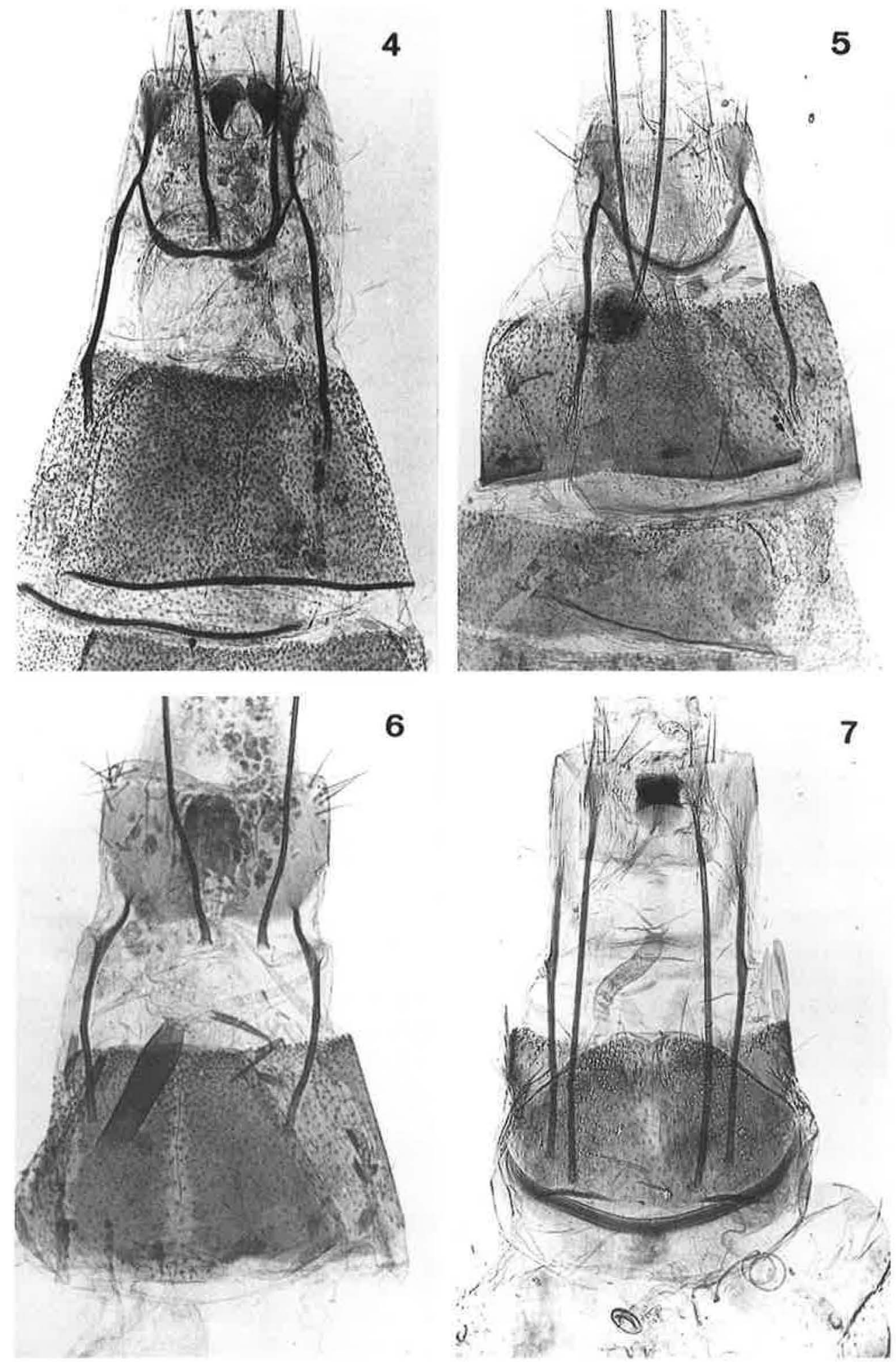

Figs. 4-7. Female genitalia of Scythris spp. - 4: Female genitalia of Scythris sp. (pr. amphonycella (Geyer)). - 5: S. baikalensis Bgts. \& Liška. - 6: S. capitalis (Erschoff). - 7: S. felesella sp. n. (holotype). 
Distribution: WC and S Europe to SW Asia.

Biology: Hostplant probably Helianthemum nummularium.

Remarks: Genitalia are described e.g. by Bengtsson (1997b). The rank of flavilaterella has been disputed for a long time. Sutter (1994) treated flavilaterella as a form of cuspidella. I prefer to consider flavilaterella as a bona species until convincing information to the contrary appears. For further discussion, see Bengtsson (1997b).

\section{Scythris fuscopterella Bengtsson, 1977}

$10^{\top}$ and 1 o: USSR, Chuckchi Pns., 64 $54^{\circ} \mathrm{N} 172^{\circ} 30^{\circ} \mathrm{W}$, $45 \mathrm{~km}$ N Provideniya, Petsovaya r. valley, 9.VII.1991, K. Mikkola.

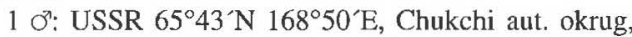
Upper Anadyr R., 700 m, mountain tundra, 21.VII.1989, K. Mikkola leg.

Distribution: On account of these data fuscopterella may be regarded an Eurasiatic species confined to the northern parts and distributed from Sweden to E Siberia.

Biology: Hostplant in N-Ural probably Epilobium latifolium and in Fennoscandia probably E. angustifolium (J. Kullberg pers. comm.).

Remark: Male and female genitalia are described by Bengtsson (1977).

\section{Scythris inspersella (Hübner, 1817)}

1 ○: Osnatjenn.; K. Ehnberg; 1499.

Distribution: A Holarctic species, principally occurring in the Boreal region.

Biology: Hostplant Epilobium angustifolium.

Remark: Genitalia are illustrated e.g. by Bengtsson (1984).

\section{Scythris jalavai Sinev, 1993}

10 and 1 Q : USSR, SW-Altai, $15 \mathrm{~km} \mathrm{~S}$ Katanda, BertKum, 2000-2 500 m, 10-14.VII.1983, Exp. Mikkola, Hippa \& Jalava leg.

Distribution: Only known from the type locality, Altai in C Asia.

Biology: Unknown.
Remarks: Male and female genitalia were described by Sinev (1993). The specimens presented here were obviously not included in the type series.

\section{Scythris kailai Bengtsson sp. $\mathrm{n}$.}

Holotype: $10^{\top}$ : USSR $43^{\circ} 24^{\prime} \mathrm{N} 75^{\circ} 2^{\prime} \mathrm{E}$, Kazakhstan, Dzhambulskaya obl., $70 \mathrm{~km}$ NNE Frunze; $950 \mathrm{~m}$, rocky slope, 15.VIII.1990 ad luc., K. Mikkola \& L. Kaila leg.

Diagnosis: May be confused with some forms of Scythris kyzylensis sp. n. (see below) but markings different. Can be separated from other species by its size in combination with the forewing markings. Also genitalia very different from those of other species.

External appearance (Fig. 9): Wingspan ca. $9 \mathrm{~mm}$, forewing ca. $4 \mathrm{~mm}$. Head, collar, tegulae and thorax dark brownish, here and there with some paler scales. Antennae distinctly ciliate, dark brownish. Forewing brownish with two blurred dirty beige blotches at $2 / 5$ and $3 / 5$ and some pale brownish scales at apex. Hindwing dark brown, narrow, width only ca. 0.6 of forewing. Cilia of both wings fuscous. Legs dark beige or fuscous. Abdomen dark greyish dorsally, dirty beige ventrally.

Male genitalia (Fig. 10a, b): Uncus and gnathos reduced, with a bristled girdle, probably homologous to socii. Valva straight, evenly broad, at tip cleft in two digitate processes of unequal length. Aedeagus rather short, bent, tapered. Sternum 8 a subtrapezoid plate with $\mathrm{M}$-shaped reinforcement, plate anteriorly incurved, posteriorly with median process. Tergum 8 a bent, narrow plate, posteromedially with long digitate process, on each side of this one small process.

Female genitalia: Unknown.

Distribution: Only known from the type locality in Kazakhstan.

Biology: Unknown. Adult found in mid August.

Etymology: Scythris kailai sp. n. is dedicated to Lauri Kaila, Helsinki, who generously has handed over this and other scythridid specimens for examination.

Remark: The species belongs to the laminella species group (see also Bengtsson 1997b). 


\section{Scythris kullbergi Bengtsson sp. n.}

Holotype: 1 Q: RUSSIA Tuva rep., $51^{\circ} 43$ N $94^{\circ} 27^{\prime} \mathrm{E}, 700 \mathrm{~m}$, Kyzyl, Nanophyton-steppe, 5-6.VI.1995, Jalava \& Kullberg leg. Genitalia on slide BÅB 688X. - In Zoological Museum, Helsinki.

Paratype: 1 Q: data as holotype. - In Zoological Museum, Helsinki.

Diagnosis: May be confused with Scythris braschiella (Hofm.) and some other European scythridids but genitalia different.

External appearance (Fig. 11): Wingspan 8.5$9.5 \mathrm{~mm}$, forewing $4.0-4.5 \mathrm{~mm}$. Head dark brownish. Basal segment of labial palpi whitish with some dark scales, number of dark scales greater on second segment, and terminal segment more or less completely brown-scaled. Antennae, collar, tegulae and thorax dark brownish. Forewing dark brownish with two plical spots of whitish scales at $1 / 4$ and $1 / 2$, surrounding a blackish spot; near tornus another blackish spot and whitish scales; at apex a dash of long whitish hairscales and whitish scales at costa near apex. Hindwing fuscous. Cilia of both wings fuscous. Legs gradually darkening from coxa to tarsi, from dirty whitish to dirty beige or brown. Abdomen rather long, tapered at tip; dorsally yellowish dark beige, ventrally mottled greyish. Segment 7 very dark brown.

Male genitalia: Unknown.

Female genitalia (Fig. 12): Sterigma triangular, tip well marked, strongly sclerotized. Sternum 7 subtrapezoid, elongate, with small labiate sclerotization at posterior margin.

Distribution: Only known from the type locality.

Biology: According to the labels of the type material collected in early June in steppe habitat (Nanophyton-steppe).

Etymology: The species is dedicated to one of the collectors of the type series, Jaakko Kullberg, Helsinki.

Remark: The female genitalia resemble some West Palaearctic scythridid species, e.g. Scythris langohri Passerin d'E \& Vives, 1990 and S. andersi Bengtsson, 1991, both from SW Europe, but until the male is found the group to which kullbergi sp. $n$. belongs cannot be settled.
Scythris kyzylensis Bengtsson sp. $\mathrm{n}$.

Holotype: $10^{\gamma}$ : RUSSIA Tuva rep., $51^{\circ} 43$ N $94^{\circ} 27^{\prime} \mathrm{E}, 700 \mathrm{~m}$, Kyzyl, Nanophyton-steppe, 5-6.VI.1995, Jalava \& Kullberg leg. - In Zoological Museum, Helsinki.

Paratypes: $140^{7} 0^{7}$ and 8 o of one male on slide $\mathrm{BA} B \mathrm{~B} 686 \mathrm{X}$ and of one female on slide $\mathrm{B} \AA \mathrm{B} 687 \mathrm{X}$. - In Zoological Museum, Helsinki.

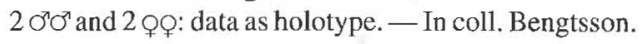

Diagnosis: May be confused with Scythris kailai sp. n. (see above) but forewing markings differ. Genitalia separate kyzylensis $\mathrm{sp}$. $\mathrm{n}$ from other scythridids.

External appearance (Fig. 13): Wingspan 7$8 \mathrm{~mm}$, forewing 3.0-3.5 mm. Head, antennae, collar, tegulae and thorax dark fuscous. Labial palpi dark fuscous, basal segment, however, ivory and anterior part of second segment with some ivory scales. Forewing dark fuscous with following more or less distinct cream-coloured markings: a transverse fascia at $1 / 3$, a fascia or two separated opposite dashes at $2 / 3$, and an apical spot. In some specimens the markings are very indistinct. Hindwing fuscous, paler at base. Cilia of both wings fuscous. Legs fuscous with dirty whitish scales on femur and on inner side of tibia (especially of hind leg). Male abdomen mottled fuscous dorsally, pale dirty brown ventrally with whitish scales on hind margin of each segment, at least on ultimate three segments. Female abdomen similar to male abdomen in coloration but segment 7 pale beige.

Male genitalia (Fig. 14a, b): Uncus bifurcate, tips pointed and outcurved. Base of gnathos a ringshaped band; terminal portion of gnathos thornlike, almost straight. Valva short, subtriangular, exterior margin convex, internal margin almost straight, valva tip rounded. Aedeagus long and thin, curved, near tip sigmoid. Sternum 8 subtriangular with deep V-shaped indentation anteriorly, and with two rounded lobes posteriorly. Tergum 8 subtrapezoid, anteriorly with deep indentation.

Female genitalia (Fig. 15): Sterigma (indicated by arrow in figure) very indistinct, a small weak triangular wrinkled sclerotization, shallowly incurved anteriorly. Sternum 7 pentangular, medioposterior extension a marked area with straight posterior margin.

Distribution: Only recorded from the type locality. 

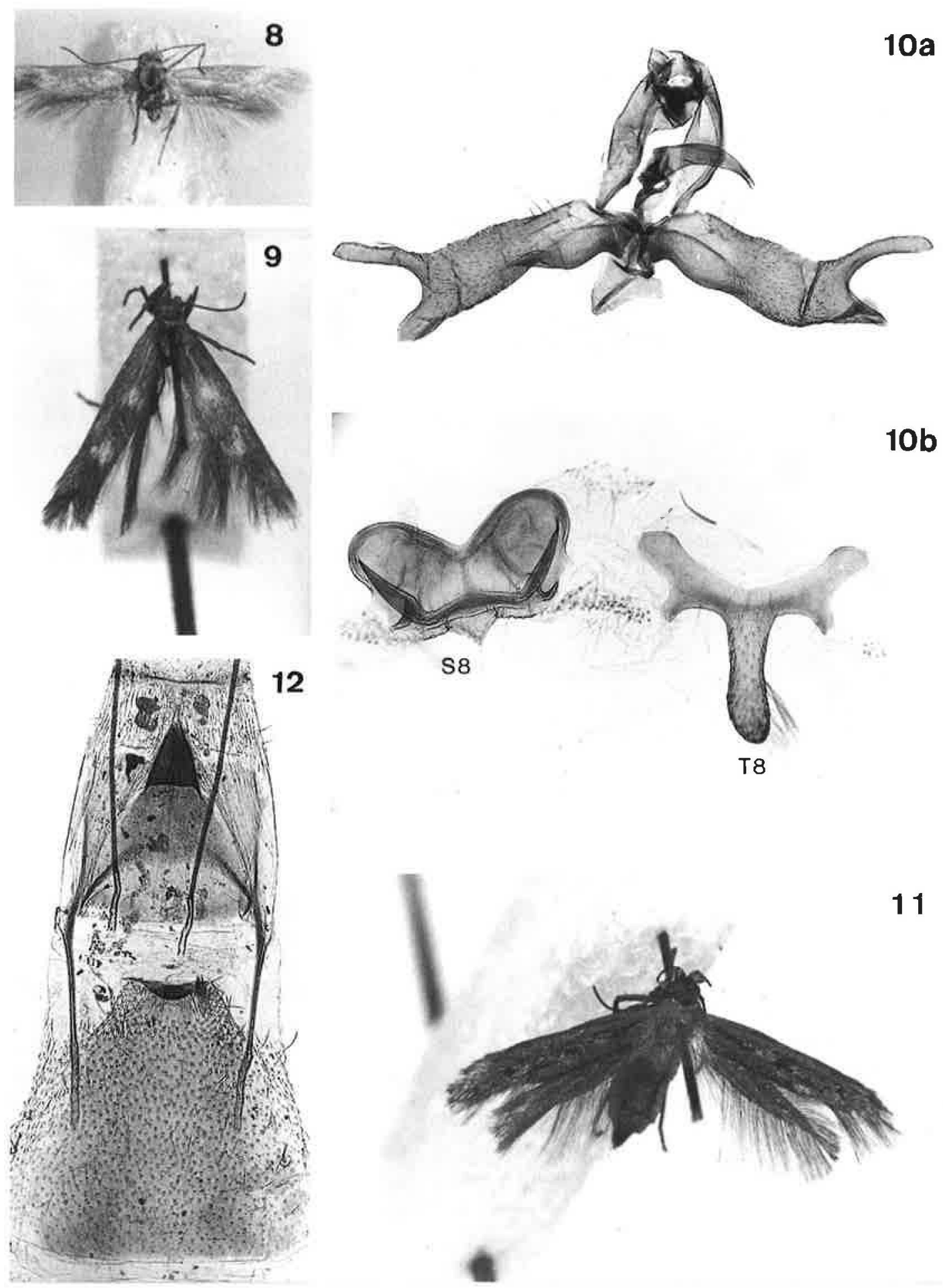

$10 b$

Figs. 8-12. - 8: Imago of Scythris felesella sp.n. (holotype). - 9: Imago of S. kailaisp.n. (holotype). - 10: Male genitalia of S. kailai (holotype), a: Uncus/gnathos/tegumen/valvae/aedeagus. b: Sternum 8 (left) and tergum 8 (right). - 11: Imago of S. kullbergi sp. n. (paratype). - 12: Female genitalia of S. kullbergi sp. n. (holotype). 

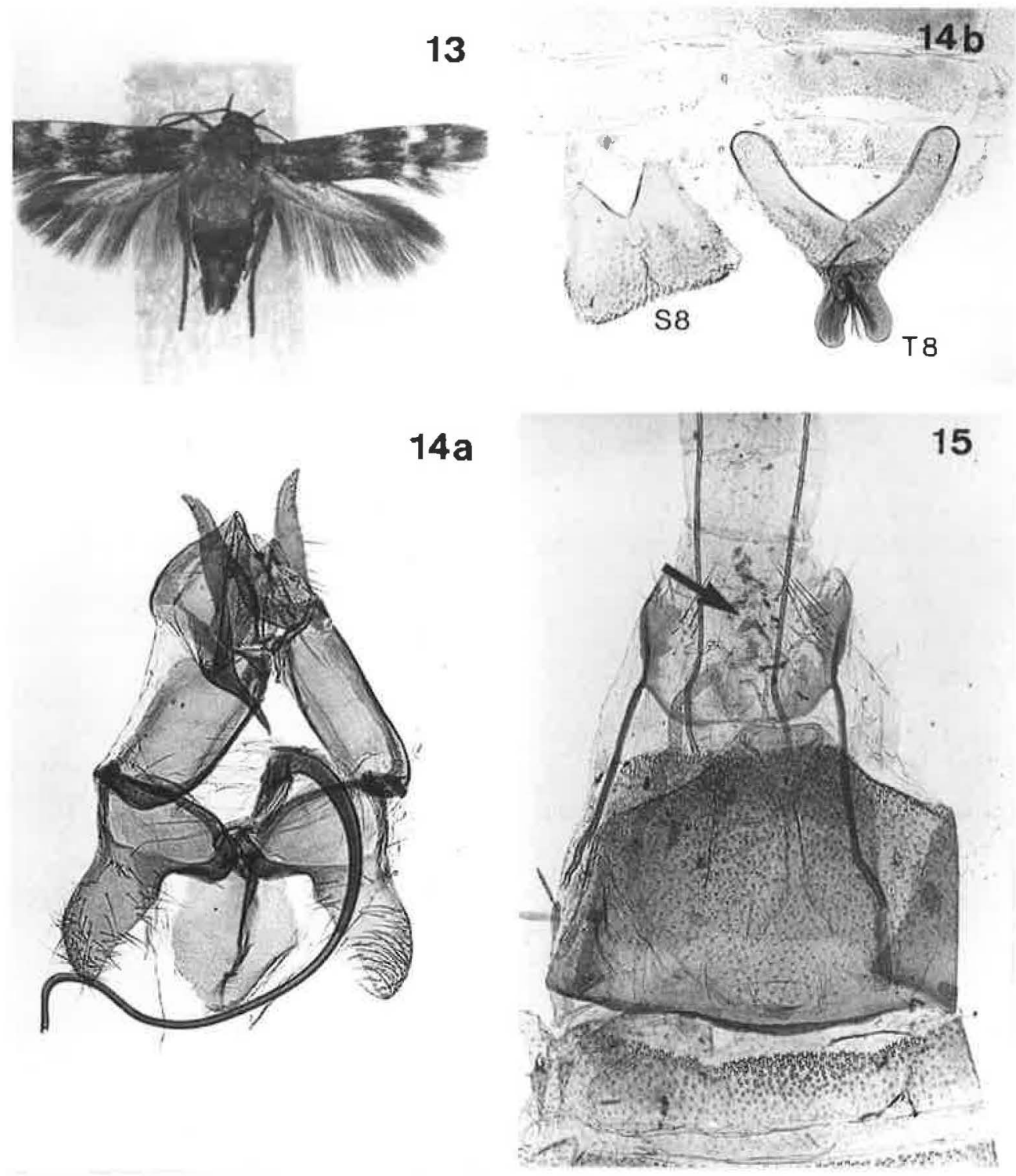

Figs. 13-15. - 13: Imago of Scythris kyzylensis sp. n. (holotype). - 14: Male genitalia of S. kyzylensis sp. n. (paratype). a: Uncus/gnathos/tegumen/valvae/aedeagus. b: Sternum 8 (right) and tergum 8 (left). - 15: Female genitalia of S. kyzylensis sp. $\mathrm{n}$. (paratype).

Biology: According to the labels collected in steppe habitat (Nanophyton-steppe). The moths were swept from flowers of Caragana sp. (Kullberg, pers. comm.).

Etymology: The species name is derived from to the type locality, Kyzyl, the capital of the Tuva Republic.

Remark: The combination of characters in male and female genitalia of S. kyzylensis sp. n. does not indicate relationship to any known species group in the Palaearctic area.

Scythris laminella (Denis \& Schiffermüller, 1775)

1 O': USSR, Siberia, Gorno-Altaisk. aut. obl., Teletsk. oz., Artybash, 18-25.VI.1990, Malaise trap, G. Ståhls leg. 
Distribution: Europe to C Asia. This record is the easternmost one known.

Biology: Hostplants Hieracium pilosella and moss (Rhytidiadelphus squarrosus) (see Bengtsson 1997b).

Remark: Genitalia are illustrated by Bengtsson (1984).

Scythris monochreella (Ragonot, 1895)

2 ơơ: U.A.E. (United Arab Emirates), Ras al Khaimah, shore dunes, light trap, 6.IV.1990, K. Mikkola leg.

Distribution: Egypt, India, Iran, Iraq, Israel, Turkey, United Arab Emirates.

Biology: Unknown.

Remark: Genitalia are described by Bengtsson (1997b).

Scythris mus Walsingham, 1898

$20^{7} \sigma^{7}$ and 1 o: SAUDI ARABIA E, nr Hamatiyat, 27.IV.1978, R. Linnavuori leg.

Distribution: From SW Europe, N Africa and S Germany east to the Arabic Peninsula.

Biology: Unknown.

Remark: Genitalia are illustrated by Bengtsson (1997b).

\section{Scythris nitidella Bengtsson \& Liška, 1996}

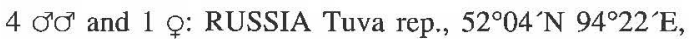
$670 \mathrm{~m}$, Ust-Ujuk, steppe hills 3-5.VI.1995, Jalava \& Kullberg leg. 1996.

Male genitalia: See Bengtsson and Liška,

Female genitalia (Fig. 16): Sterigma shaped as the Greek letter $\pi$ (pi) when flattened out, the posterior transverse portion in situ (i.e before flattening the genitalia) lying at right angles to the two anterior sclerotizations, thereby forming a shelf. The intersegmental membrane posterior sterigma densely and minutely spined.

Biology: Unknown.

Remark: S. nitidella was recently described (Bengtsson \& Liška, 1996) on the basis of one male specimen in good shape collected in North
Korea. By the data from Tuva Republic the distribution range has been considerably extended westward.

Scythris nivicolor Meyrick, 1916

10 o: Israel, Eilat, 19-20.III.1978, K. Mikkola leg.

Distribution: This species was originally described from India but has also been found in $\mathrm{Pa}$ kistan and is now recorded from Israel, as well.

Biology: Unknown.

Remark: Genitalia are illustrated by Bengtsson (1997a).

Scythris picaepennis (Haworth, 1828)

1 ơ: USSR $43^{\circ} \mathrm{N} 43^{\circ} \mathrm{E}, \mathrm{C}$. Caucasus, Kabardino-Balkarskij 7.ap. $35 \mathrm{~km} \mathrm{SE} \mathrm{mt.} \mathrm{Elbrus,} \mathrm{alpine} \mathrm{meadow} 2600 \mathrm{~m}$, 12.VII.1990, J. Jalava leg.

Distribution: C and S Europe, Caucasus, Japan. The large gap between Caucasus and Japan is probably only reflecting the lack of collecting.

Biology: Lotus corniculatus, Thymus vulgaris, Helianthemum, Succisa and Plantago have been mentioned as hostplants (see Bengtsson 1997b).

Remark: Genitalia are illustrated by Bengtsson (1984).

Scythris sinensis (Felder \& Rogenhofer, 1875)

1 ơ: Utoschkina; K. Ehnberg; 116.

Distribution: During the recent decades found in many European countries but first described from $\mathrm{E}$ Asia (Amur). Distribution ranges from England to Korea/Japan/Taiwan.

Biology: Hostplant Chenopodium album.

Remark: S. sinensis is a polymorphic species and is thus described under several names, now regarded as synonyms (see Bengtsson 1997b). Genitalia are illustrated by Bengtsson (1984).

Scythris subcassiterella Bengtsson sp. $\mathrm{n}$.

Holotype: 1 ơ: USSR Primorje, Kedrovaja pad, 2730.VI.1992, K. Mikkola leg. Genitalia on slide BÅB 485X. — In Zoological Museum, Helsinki. 
Paratypes: 1 ơ: Sutchan 90 B. ot (Sučan, near Vladivostok) (handwritten). Genitalia on slide Pa 2395. In coll. ZMHB [Berlin].

1 ơ: (no data but probably from the same locality as the previous paratype). Genitalia on slide $\mathrm{Pa} 2396$. - In coll. ZMHB (Berlin).

Diagnosis: Very similar to many other dark, slightly bronzy or olive fuscous scythridids, e.g. Scythris cassiterella (Snellen, 1884) and S. flavilaterella. Only dissection of genitalia can give safe determination.

External appearance (Fig. 17): Wingspan ca. $14 \mathrm{~mm}$. Head, antennae, labial palpi, tegular, thorax, forewings and legs dark bronzy fuscous, forewing moderately glossy; labial palpi rather small. Abdomen dark fuscous, anal tuft sparse, brownish beige.

Male genitalia (Fig. 18a-d): Uncus a setose squared membrane. Gnathos stout, thorn-shaped. Valvae asymmetrical, each with small flap near base; left one short and broad, subtriangular; right one slightly curved, digitate, with swollen base. Aedeagus atypical for a scythridid, manica with lateral process, distal portion of aedeagus spatular with a large number of minute spines. Tergum 8 a semicircular plate. Sternum 8 Y-shaped, distal end asymmetrical with a bent irregular lobe.

Female genitalia: Unknown.

Distribution: Recorded from the Primorye district in the easternmost part of Russia.

Biology: Unknown.

Etymology: The species name refers to the close affinity in external appearance and in genital morphology to $S$. cassiterella.

Remarks: The shape of aedaegus in cassiterel$l a$ and subcassiterella might constitute an apomorphy of a subgeneric group. Maybe also S. chrysopygella Caradja, 1927 (from China) should be included in this small group but the aedeagus has not been studied.

\section{Scythris terekholensis Bengtsson sp. n.}

Holotype: $1 \sigma^{7}$ : RUSSIA Tuva rep., $50^{\circ} 01^{\prime} \mathrm{N} 95^{\circ} 03^{\prime} \mathrm{E}$, $1150 \mathrm{~m}$, Lake Tere-Khol, sand dunes, 9-12.VI.1995, Jalava \& Kullberg leg. Genitalia on slide BÅB 689X. - In Zoological Museum, Helsinki.

Paratypes: $3 \sigma^{\top} \sigma^{\top}$ and $3 \circ Q$ with same data, genitalia of

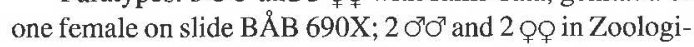
cal Museum, Helsinki, $1 O^{n}$ and $1 \%$ in coll. Bengtsson.
Diagnosis: Can be confused with a few, still undescribed species from Pakistan and India but genitalia are quite different.

External appearance (Fig. 19): Wingspan 9$10 \mathrm{~mm}$, forewing 4.0-4.5 mm. Crown dark brown, rest of head whitish. Labial palpi whitish but terminal segment with some brownish scales. Antennae about 0.6 of forewing length, irregularly covered with white and blackish brown scales, scape whitish ventrally. Collar and tegulae brown beige. Thorax dark brownish. Forewing slender, dark brownish in dorsal half, costal region covered with pale brownish scales; wing surface covered with scattered whitish scales, concentrated to spots or dashes in fold at $3 / 8,5 / 8$ and, especially, in apical area; cilia fuscous but some whitish hair-scales in apical fringes; underside of forewing covered with whitish scales on dark brownish background. Hindwing pale fuscous, at base almost whitish, apically brownish; cilia dirty beige. Legs whitish but dorso-posterior surface of tibia and tarsi to a great extent dark brown. Abdomen in male dorsally dark greyish beige, ventrally ivory; anal brush small and sparsely tufted.

Male genitalia (Fig. 20a, b): Uncus reduced, tegumen with asymmetrical extension posteriorly. Gnathos conspicuous, strongly sclerotized, dentate, tip rounded, attached to tegumen along a curved ventral ridge. Valvae fused at base, spatular, posterior subtriangular half covered with stout pegs. Aedeagus small with oblique tip. Sternum 8 a subrectangular membrane. Tergum 8 a wide plate with two posterior digitate extensions.

Female genitalia (Fig. 21): Sterigma elongately conical, tip cylindrical and blunt. Sternum 7 also conical, elongate, tip medially with small triangular sclerotization, on each side with a small "shoulder".

Distribution: Only known from the type locality.

Biology: Unknown. Imago found in early June. All type specimens were collected in one sweeping from Astragalus/Vicia-plants on a sand dune.

Remark: The strongly sclerotized pegs or spines on valvae in male genitalia indicate seemingly some relationship with $S$. tityrella Falkovitch, 1969 known from Uzbekistan but other characters contradict this statement. The female 


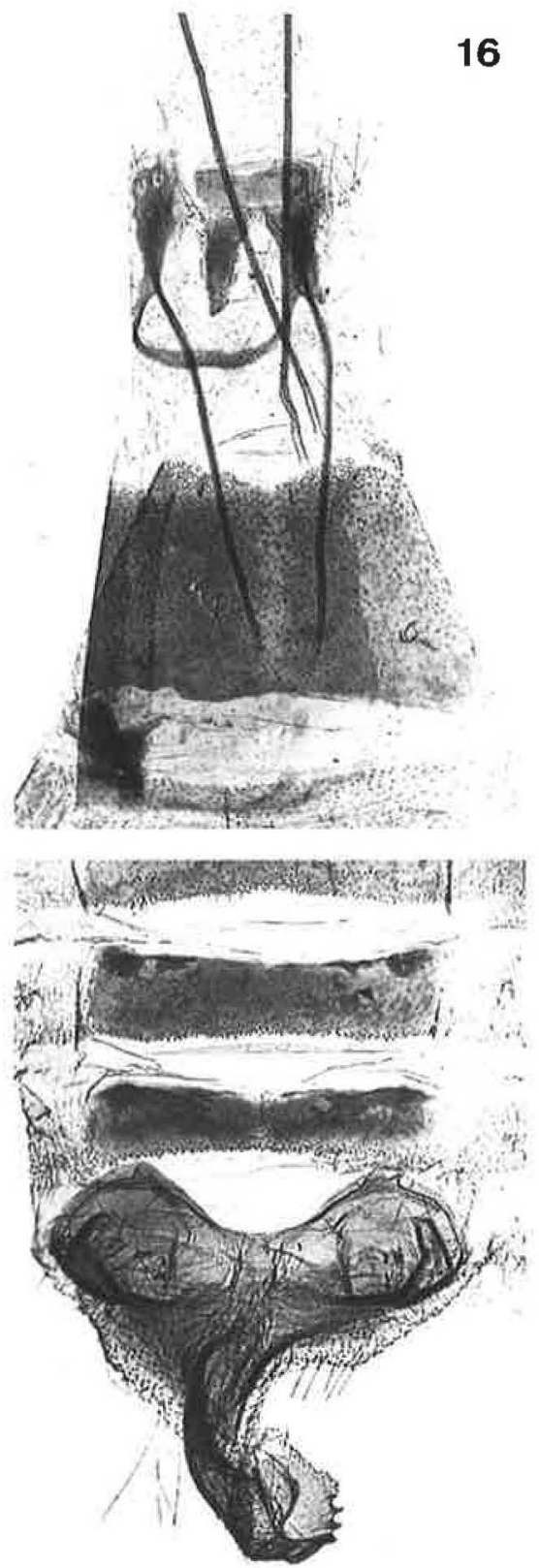

$18 c$

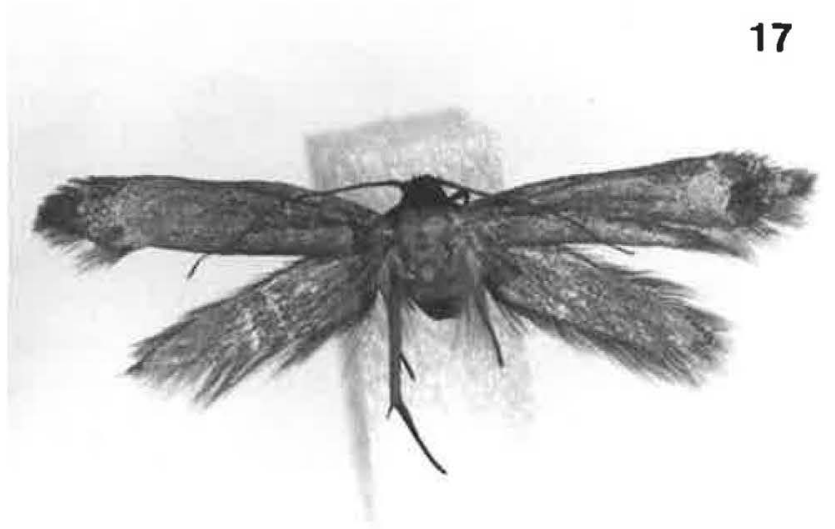

$18 a$

$18 b$
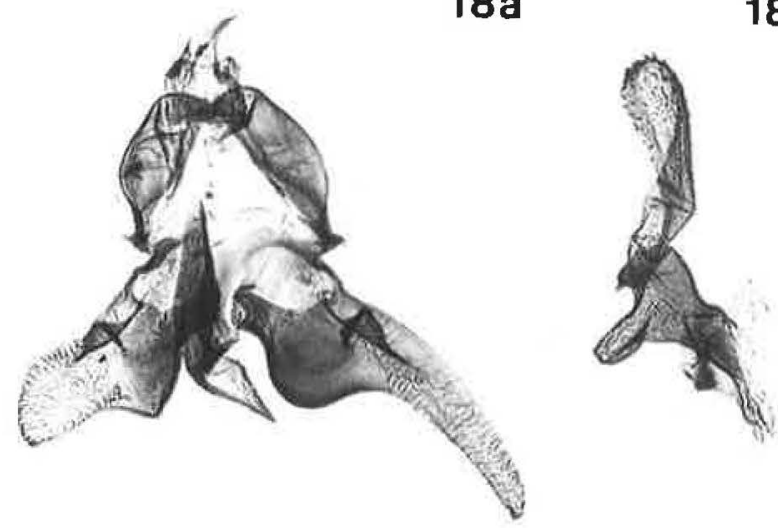

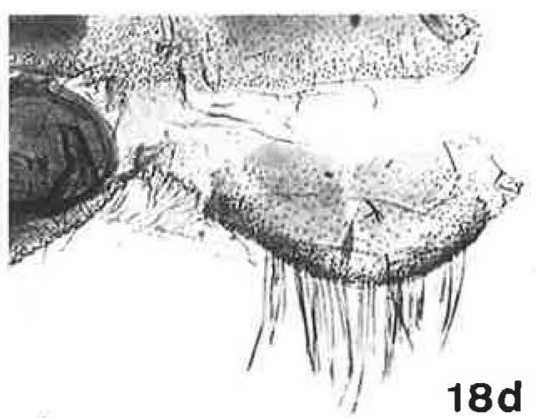

Figs. 16-18. - 16: Female genitalia of Scythris nitidella Bgts. \& Liška. - 17: Imago of S. subcassiterella sp. $n$. (holotype). - 18: Male genitalia of S. subcassiterella sp. n. (holotype). a: Uncus/gnathos/tegumen/valvae. b: Aedeagus. c: Sternum 8. d: Tergum 8.

Figs. 19-23 (Right). - 19: Imago of Scythris terekholensis sp. n. (holotype). - 20: Male genitalia of S. terekholensis sp. n. (holotype). a: Gnathos/tegumen/valvae/aedaegus. b: Sternum 8 (top right) and tergum 8 (bottom right). - 21: Female genitalia of $S$. terekholensis sp. n. - 22: Imago of S. bifissella (Hofmann). - 23: Male genitalia of $S$. bifissella (Hofmann). a: Uncus/gnathos/tegumen/valvae/aedeagus. b: Sternum 8 (top right) and tergum 8 (bottom right). 

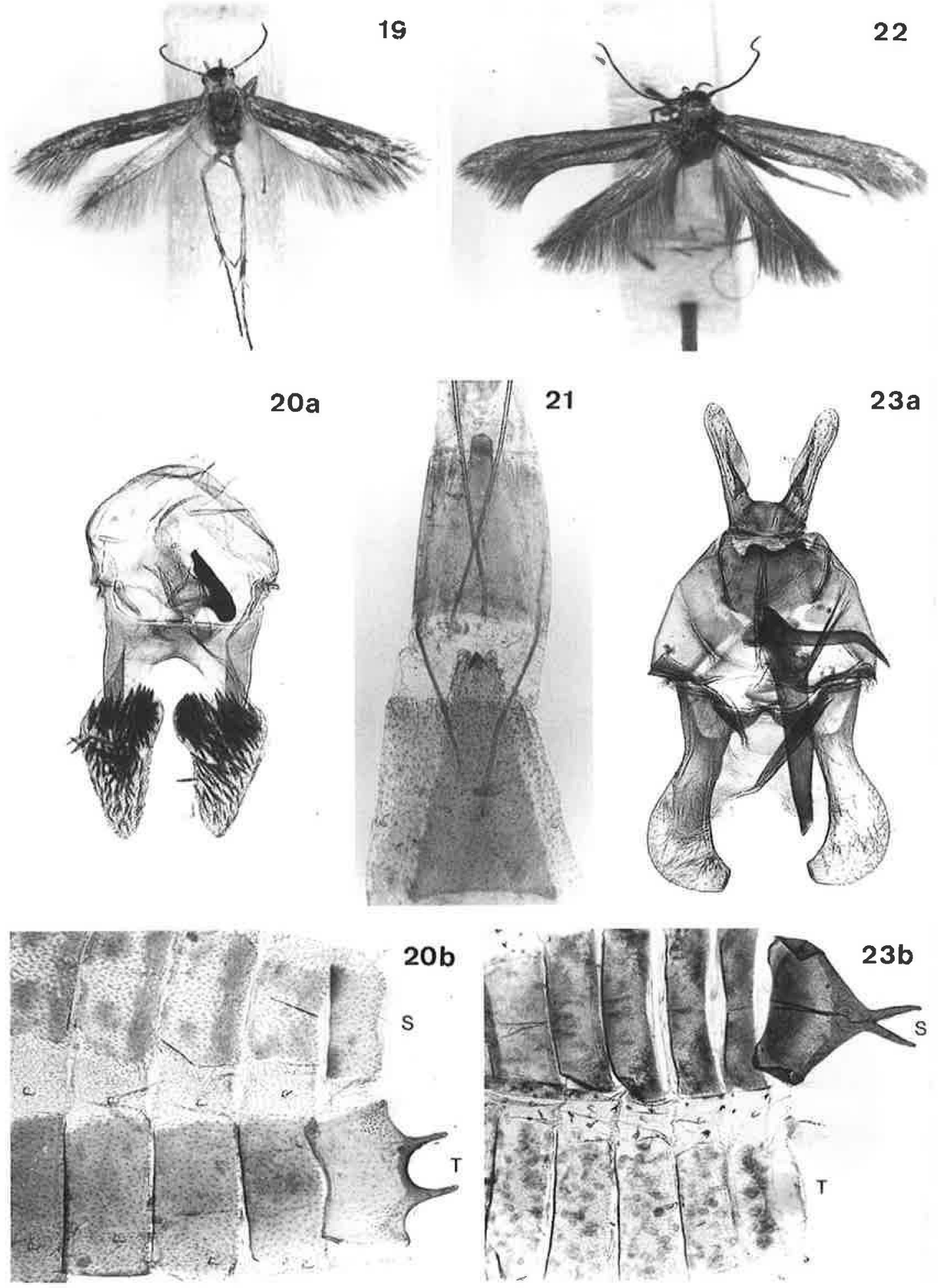
genitalia give no hint to which group to refer terekholensis sp. $\mathrm{n}$.

Scythris tessulatella Rebel, 1903

$10^{\text {? }}$ TUNISIA, Sahara, Douz Oasis, 16.IV.1984, K. Mikkola leg.

Distribution: Algeria, Libya, Tunisia.

Biology: Unknown.

Remark: Genitalia are illustrated by Bengtsson (1997b).

Acknowledgements. I am in great debt to Jukka Jalava, Lauri Kaila and Jaakko Kullberg at the Zoological Museum in Helsinki who made it possible for me to study this valuable material of Scythrididae. My sincere thanks to Dr. David Agassiz, London, U.K., for correcting the language.

\section{References}

Bengtsson, B. A. 1977: Two new species of Microlepidoptera from northem Sweden (Lepidoptera: Elachistidae, Scythrididae). - Entomologica Scandinavica 8: 55-58.

Bengtsson, B. $\AA$. 1984: The Scythrididae of Northern Europe. - Fauna Entomologica Scandinavica, Vol. 13. Brill, Leiden/Copenhagen. 137 pp.

Bengtsson, B. Å. 1997a: Scythridids found by H.Hacker in Pakistan 1988 and India 1992. — Esperiana. (In press.)

Bengtsson, B. Å. 1997b: Microlepidoptera of Europe. Scythrididae. - Apollo Books, Stenstrup. (In press.)

Bengtsson, B. A. \& Liška, J. 1996: Notes on Asian scythridids with description of four new species (Lepidoptera: Scythrididae). — Phegea 24: 33-39.

Bengtsson, B. A. \& Sutter, R. 1996: Scythris felixi sp. n. (Insecta, Lepidoptera: Scythrididae) aus der Mongolei. Reichenbachia Mus. Tierk. Dresden 31, Nr. 37: 207-208.

Sutter, R. 1994: Beiträge zur Insektenfauna Ostdeutschlands: Lepidoptera-Scythrididae. - Beitr. Ent. 44: 261-318. 